\title{
CITY-LEVEL HUKOU-BASED LABOR MARKET DISCRIMINATION AND MIGRANT ENTREPRENEURSHIP IN CHINA
}

\author{
Jie $\mathrm{CHEN}^{1}$, Mingzhi $\mathrm{HU}^{2 *}$ \\ ${ }^{1}$ School of International and Public Affairs \& China Institute for Urban Governance, \\ Shanghai Jiao Tong University, 200240 Shanghai, China \\ ${ }^{2}$ School of Management \& Chinese Academy of Housing and Real Estate, \\ Zhejiang University of Technology, 310014 Hangzhou, Zhejiang, China
}

Received 20 September 2020; accepted 11 April 2021; first published online 05 July 2021

\begin{abstract}
A previously undocumented association between city-level degree of hukou-based labor market discrimination and migrant's individual entrepreneurship engagement is examined. Applying the Oaxaca-Blinder decomposition analysis on the micro data from the China Migrants Dynamic Survey (CMDS) suggests that hukou-based labor market discrimination can on average explain a $6.3 \%$ differential in personal income for rural migrants relative to otherwise identical urban migrants. A one standard deviation increase in a city's average hukou-based labor market discrimination is associated with roughly 2.9 percentage point higher of entrepreneurship rate among rural migrants, holding other things equal. Furthermore, city-level hukou-based labor market discrimination is associated with much higher propensity for engagement in necessitybased entrepreneurship compared with opportunity-based entrepreneurship. Our empirical work also suggests that the association between city-level hukou discrimination and migrant entrepreneurship is more prominent for people with middle level of education, young people, married people, and renters. Policy implications of these findings are discussed.
\end{abstract}

Keywords: hukou discrimination, labor market, migrant entrepreneurship, China.

JEL Classification: M13, N35, J71.

\section{Introduction}

Entrepreneurial activeness are crucial for both national economic prosperity and regional competitiveness (Naudé, 2011; Parker, 2005; Stephens et al., 2013). The existing studies have found that personal entrepreneurial propensity is associated with many region-specific contextual factors, such as institution, culture, financial constraint and group-specific social resource (Acs et al., 2008; Guo \& Miller, 2010; Simoes et al., 2016; Westlund \& Bolton, 2003).

${ }^{\star}$ Corresponding author. E-mail: hu_mingzhi@outlook.com

Copyright (c) 2021 The Author(s). Published by Vilnius Gediminas Technical University

This is an Open Access article distributed under the terms of the Creative Commons Attribution License (http://creativecommons. org/licenses/by/4.0/), which permits unrestricted use, distribution, and reproduction in any medium, provided the original author and source are credited. 
However, so far no literature has explored how the city-level degree of group-specific labor market discrimination correlates with the decision of those discriminated against to enter entrepreneurship. A large body of literature that incorporating gender and racial-based discrimination into the theoretical and analytical framework of entrepreneurship shows that group-specific labor market discrimination can explain differences in the entry rate of entrepreneurship among different groups (Coate \& Tennyson, 1992; Köllinger \& Minniti, 2006; Muravyev et al., 2009; Rosti \& Chelli, 2005; Williams, 2012). The key argument in this strand of literature is labor market discrimination implies that those discriminated against face higher barrier to high-paid jobs (Clark \& Drinkwater, 2000), more blocked mobility (Raijman \& Tienda, 2000), and then lower opportunity cost of entrepreneurship (Simoes et al., 2016). It is therefore those discriminated against are predicted to have higher tendency to transit into entrepreneurship or self-employment. Nonetheless, the existing literature on this topic generally studies the effect of individual-level perceived discrimination but have not attempted to investigate the impact of regional-level or city-level discrimination extent on the entrepreneurship decisions of those discriminated against.

This paper extends the literature on the association between regional contextual factors and individual's entrepreneurship mainly in three aspects. First, it estimates the aggregatelevel discrimination extent of local labor market, where existing literature estimates either individual-level or group-level discrimination extent. This extension can help to better understand features of the social amenity or "friendliness" of local labor market. Second, it studies the effect of city-level labor market discrimination extent on rural migrants, the group which are arguably most vulnerable as well as most sensitive to discrimination circumstance. We thus provide the first scientific assessment of which cities are more friendly and inclusive to rural migrants in China. Third, it focuses on examining how the disadvantageous social identity generated by formal institutional factors contributes to the gap in entrepreneurship entry between the underclass and the privileged. Our analysis is derived with reference to China's unique household registration system (or hukou system in Chinese, which significantly affects migrants' access to local public service as well as labor market ladder (Chan, 2013; Chan \& Buckingham, 2008). We design a framework to investigate how the disadvantageous social identities generated by the hukou system affect the distribution of earnings between migrants with a rural hukou (rural migrants) and those with an urban hukou (urban migrants), and how further such labor market disadvantage spillovers to their entrepreneurial engagement. Our main hypothesis is that hukou-based discrimination in the salaried labor market, by lowering down the ladder potential in the labor market and then reducing the opportunity costs of entrepreneurship, increases the incentives of migrants being discriminated against to start their own business. This is because discrimination lowers the expected labor returns in the labor market, and thus decreases the opportunity cost of entrepreneurship.

The analysis in this paper proceeds in three stages. First, we apply the Oaxaca-Blinder decomposition analysis on the micro data from the China Migrants Dynamic Survey (CMDS) to show how much earnings gap between rural migrants and otherwise identical urban residents, attributing this unexplained gap to hukou-based labor market discrimination. Our results indicate that rural migrants have a personal income less than $6.3 \%$ of their comparable urban migrants. Second, we compute the city-level average extent of hukou-based 
discrimination and discuss its distribution. Third, and the most essential component of our analysis, we link city-level hukou-based discrimination indicator to individual rural migrant's entrepreneurship engagement propensity. We find that, a one standard deviation increase in a city's hukou discrimination is associated with 2.9 percentage points higher of the entrepreneurship rate among rural migrants, holding other things equal. We also investigate the effect of hukou discrimination on two types of entrepreneurship and find that rural migrants are largely pushed into entrepreneurship out of necessity, rather than pulled into this endeavor out of choice to take advantage of some business opportunity. Last, our findings indicate that the association between hukou discrimination and migrant entrepreneurship is more prominent for people with middle level of education, young people, married people and renters.

The remaining parts of this paper are structured as follows. Section 1 places our research in the context of existing literature and posits relevant hypotheses. Section 2 describes the data, variables and empirical approaches. Section 3 and Section 4 present the results of the preliminary analysis and regression analysis, respectively. The final section concludes this article with policy implications.

\section{Literature review and hypotheses development}

The literature has long stressed that local circumstance and social environment is crucial to understand individual's decision to launch own business or embark self-employment. For example, it is argued that, "business start-up can be understood in terms of situations people encounter" (Shane et al., 1991). Theories like "social marginality" propose that sociological determinants offer important indicators to predict who are more likely to make a transition to self-employment (Stanworth et al., 1989). The applicability of social determinant theory in the field of entrepreneurship is particularly relevant for understanding the entrepreneurial decisions of socially disadvantaged groups (Bates et al., 2007; Simoes et al., 2016). Particularly, hostile social circumvent reduces disadvantaged group's chance of upward mobility in labor market and pushes them into self-employment as an escape strategy (Raijman \& Tienda, 2000; Rosti \& Chelli, 2005; Williams, 2012).

For example, it has been long observed that immigrants are more likely than the nativeborn population to try starting a business (Kahn et al., 2017; Köllinger \& Minniti, 2006). Many scholars argue that an important factor that motivates immigrants to the direction of self-employment is labor market discrimination. Previous studies conducted in developed countries have found that immigrants are discriminated against in several aspects in the labor market (Müller, 2003; Raijman \& Tienda, 2000). On the other hand, it is widely suggested that individuals are more likely to be pushed into self-employment when they feel discriminated in the labor market (Constant \& Zimmermann, 2006; Raijman \& Tienda, 2000). Many studies have found evidences that labor market discrimination against immigrants impacts the decision to enter entrepreneurship for immigrants in west countries (Kahn et al., 2017; Simoes et al., 2016).

The institutional discrimination and social hostile against migrants in urban China, referring to those without local hukou in the host cities, has long discussed in the literature (Chan \& Zhang, 1999). Since the success of the communist revolution in China in 1949, 
the Chinese government has retained extremely tight controls on migration across regions through the management of the hukou system and under this system all citizens have to register their hukou location (either local or non-local) and hukou type (either rural or urban) (Afridi et al., 2015; Chan \& Buckingham, 2008; Liu, 2005). Before the beginning of reform and opening-up policy in 1978, the hukou system in China was equivalent to an internal visa arrangement to control internal migration and particularly, rural hukou holders were forbidden to migrate into cities without government permission (Chan, 2013). Although the hukou management becomes loose over time since the market-oriented reform (Chan \& Buckingham, 2008; Lu \& Wan, 2014), it is still a salient feature of the Chinese society.

The literature has suggested that migrants in Chinese cities are discriminated against in a variety of ways. First, migrants are almost excluded from local public services and social benefits that directly or indirectly associated with hukou status such as social security, subsidized housing, and children's access to local public schools (Afridi et al., 2015; Chan, 2013). Second, migrants have less employment opportunities and their salaries are generally lower than otherwise comparable natives in the urban areas. Migrants are often not eligible to apply for positions in public sectors and state-owned work units (Ma, 2018). The labor market discrimination against migrants is especially pronounced for rural-to-urban migrants (Meng \& Zhang, 2001).

Rural migrants are often discriminated again in the urban labor market because of hukou status restriction, low human capital, lack of social networks (Liu, 2005), and thus they generally have lower reservation wage. Démurger et al. (2009) show that $81 \%$ of rural migrants are reported to have been discriminated against in career promotion, $82 \%$ in housing distribution, and $85 \%$ in social welfare. Generally, labor market discrimination created by the hukou system falls into three categories: wage discrimination, hiring discrimination and premarket discrimination (Song, 2014). Many studies document that there is a significant wage discrimination against rural-to-urban migrants in China's urban labor market (Démurger et al., 2009; Lee, 2012; Song, 2014; Zhang et al., 2016). Specifically, Gagnon, Xenogiani, and Xing (2011) compare the wage in three groups (urban residents, urban migrants and rural migrants) by using the data from the 2005 Chinese national census survey. They find that wages are lowest for rural migrants and highest for urban residents; besides, rural migrants earn nearly $40 \%$ less than urban migrants and almost $40 \%$ of this wage differential cannot be explained by observables. Given the disadvantaged position in the labor market for rural migrants and then the lower opportunity cost of entrepreneurship, it is therefore reasonable to expect they are more likely to turn to self-employment or start their own businesses. There are thus also straightforward to anticipate that rural migrants would have more entrepreneurship tendencies in the circumstances where they perceive their value of working are more underestimated in the labor market. On the basis of the above discussions, we posit the first hypothesis as following:

Hypothesis 1. Rural migrants' entrepreneurship engagement would be higher in the cities where hukou-based labor market discrimination is more serve.

Previous studies also suggest that people are either pushed into entrepreneurship out of necessity or pulled into entrepreneurship out of opportunity (Constant \& Zimmermann, 
2006; Wei et al., 2019). Pull motivations arise from a variety of aspects. Shane, Kolvereid, and Westhead (1991) are one of the first to discuss the motivational components of opportunitybased entrepreneurs, which include recognition, independence, learning and roles. Birley and Westhead (1994) further identify seven categorizations of pull motivations, including the need for approval, need for independence, need for personal development, need for welfare improvement, perceived instrumentality of wealth, tax reduction and indirect benefits, and following role models. A multitude of other pull motivations, such as autonomy, achievement, respect, recognition and self-realization, are documented in follow-up studies (Carter et al., 2003; Liu, 2012). Necessity-based entrepreneurs are also driven by a range of motivational factors. Unemployment is the most discussed factor explaining the decision to become self-employed. Individuals have three options in the labor market: unemployment, entrepreneurship and wage employment. Oxenfeldt (1943) argues that individuals will be more likely to start their own businesses to earn a living when they cannot find a job or face low prospects for wage employment. Several empirical studies provide supportive evidence for the entrepreneurship pushed by the intention of escaping from unemployment (Rocha et al., 2015; Thurik et al., 2008). Apart from unemployment, there are other factors that may push individuals into entrepreneurship, such as family pressure and job dissatisfaction (Hisrich \& Brush, 1986; van der Zwan et al., 2016). The entrepreneurial intentions of Chinese rural migrants, who are discriminated against in the labor market by their hukou status, are reasonably believed to be motivated more by "push" factors rather by "pull" factors. It is also reasonable to expect the influence of "push" factors would be stronger in the circumstances where labor market discrimination is more serve. On the basis of the above analysis it is possible to posit the second hypothesis:

Hypothesis 2. The correation between rural migrants' entrepreneurship engagement and city-level hukou-based labor market discrimination would be strong for necessity-based entrepreneurship but weak for opportunity-based entrepreneurship.

\section{Data, variables and empirical approach}

\subsection{Data source and sample description}

We combine two datasets for this study: China Migrants Dynamic Survey (CMDS) (National Health Commission of China, 2016) and China City Statistical Yearbook (CCSY) (National Bureau of Statistics of China, 2017). CMDS is a micro-level dataset, which is a nation-wide household survey conducted annually by the Migrant Population Service Center at National Health Commission of China. CMDS collects detailed information of migrants on demographic and socio-economic characteristics. Sample points are randomly selected from the places where the floating population is relatively concentrated. A stratified three-stage scaled probability proportional to size sampling (PPS) is used in this survey for a better representation of Chinese society. Respondents are restricted to migrants (those aged 15 or above) who have a non-local hukou and have resided in the current city for one month and longer. We use the 2016 CMDS that is the most up-to-date public-accessible data. Roughly 169,000 individuals in 31 mainland provinces or their administrative equivalents (municipalities and 
autonomous regions) in China are interviewed in 2016. See more details about CMDS in a number of recent papers that based on this dataset (Chen \& Wang, 2019; Zou et al., 2019).

We apply three screenings to the sample. First, considering that labor market activities most happen in urban areas, we restrict our attention to the urban areas by eliminating sample observations in the rural areas ${ }^{1}$. Second, we restrict samples in our analysis to working age adults between 20 and 60 years. Third, we eliminate observations with missing value of key information. The final sample contains a total of 61,621 observations from 72 cities located in 30 provinces in mainland China, of which 48,908 migrants are identified as having an agricultural hukou (rural migrants hereafter), and the remaining 12,713 are those who have a non-agricultural hukou (urban migrants hereafter). City-level data are obtained from the 2017 China City Statistical Yearbook (CCSY), conducted by the National Statistics Bureau of China. All data indicated in the statistical yearbook are data in the previous year. We use several city-level context variables that are suggested to have effects on individual's entrepreneurial engagement; these include GDP, industrial structure, unemployment rate, wage, loan to deposit ratio and housing price (Chen \& Hu, 2019; Glaeser et al., 2010).

Table 1 displays the summary statistics of the variables in the sample. The entrepreneurship rate for the full sample (including both rural and urban migrants) is $39.6 \%$. This figure is much higher compared with that of urban residents (around 8\%) (Chen \& Hu, 2019), but broadly consistent with findings in another national survey which suggests that the self-employment rate among Chinese migrant labors is $28 \%$ in 2009 (Meng, 2012). Furthermore, the average entrepreneurship rate is $43.2 \%$ for rural migrants but only $25.7 \%$ for urban migrants, and the difference is statistically significant at the one percent level. This finding suggests that unconditionally rural hukou status is associated with higher probability of entrepreneurial engagement. We can also see that most individual \& household characteristics and city-level variables vary significantly between rural and urban migrants, suggesting that conclusions regarding the correlation between hukou status and entrepreneurial engagement warrant further investigation by controlling for these characteristics.

\subsection{Measurement of hukou discrimination in the labor market}

The Oaxaca-Blinder method is often used to analyze differences in labor market returns between groups (Démurger et al., 2009; Fossen, 2012; Ma, 2018). Here we use it to analyze differences in labor income between employed urban and rural migrants. The Oaxaca-Blinder decomposition normally has two steps. The first step is to regress income on individual's demographic and socio-economic characteristics separately for two subgroups based on the linear model:

$$
\operatorname{Ln}\left(\text { Income }_{l}\right)=X_{l}^{\prime} \beta_{l}+\varepsilon_{l} \text { for } l \in\{u, r\},
$$

where $l$ indicates the group: $u$ refers to urban migrants and $r$ refers to rural migrants; Income is a vector of incomes of individuals, $X_{l}$ is a matrix of covariates, and $\varepsilon_{l}$ is the error term.

\footnotetext{
${ }^{1}$ In China community is the smallest statistical unit, which is defined by a village committee (cunweihui) in rural areas or a neighborhood committee (juweihui) in urban areas. All respondents in the CMDS are identified into these two types of neighborhoods.
} 
Table 1. Summary statistics (source: Individual and household data are obtained from the National Health Commission of China, 2016; City-level data are obtained from National Bureau of Statistics of China, 2017)

\begin{tabular}{|c|c|c|c|c|c|}
\hline Variable & $\begin{array}{c}\text { Full } \\
\text { sample }\end{array}$ & $\begin{array}{c}\text { Rural } \\
\text { migrants }\end{array}$ & $\begin{array}{l}\text { Urban } \\
\text { migrants }\end{array}$ & $\begin{array}{l}\text { The mean } \\
\text { differences }\end{array}$ & p-Value \\
\hline \multicolumn{6}{|c|}{ Individual \& household characteristics } \\
\hline Rural hukou & 0.794 & & & & \\
\hline Entrepreneur & 0.396 & 0.432 & 0.257 & 0.175 & 0.000 \\
\hline 4-year college or above & 0.100 & 0.046 & 0.308 & 0.262 & 0.000 \\
\hline 3-year college & 0.137 & 0.106 & 0.257 & 0.151 & 0.000 \\
\hline Middle \& high school & 0.673 & 0.739 & 0.417 & 0.322 & 0.000 \\
\hline Primary school & 0.09 & 0.109 & 0.019 & 0.090 & 0.000 \\
\hline Male & 0.559 & 0.561 & 0.548 & 0.013 & 0.009 \\
\hline Age & 34.96 & 34.96 & 34.97 & 0.010 & 0.909 \\
\hline Han & 0.947 & 0.948 & 0.943 & 0.005 & 0.023 \\
\hline Married & 0.813 & 0.817 & 0.796 & 0.021 & 0.000 \\
\hline Communist & 0.045 & 0.029 & 0.109 & 0.080 & 0.000 \\
\hline Household income & 7,581 & 7,134 & 9,302 & 2,168 & 0.000 \\
\hline Homeowner & 0.275 & 0.236 & 0.424 & 0.188 & 0.000 \\
\hline Observation & 61,621 & 48,908 & 12,713 & & \\
\hline \multicolumn{6}{|c|}{ City-level information } \\
\hline GDP & $59,700,000$ & $91,100,000$ & $119,059,100$ & $27,959,100$ & 0.000 \\
\hline Industrial structure & 50.58 & 54.75 & 59.17 & 4.422 & 0.000 \\
\hline Unemployment rate & 0.046 & 0.045 & 0.043 & 0.002 & 0.000 \\
\hline Wage & 67,922 & 74,982 & 82,392 & 7,410 & 0.000 \\
\hline LTD & 0.747 & 0.795 & 0.748 & 0.047 & 0.000 \\
\hline Housing price & $7,063.35$ & $8,688.49$ & $9,982.71$ & 1,294 & 0.000 \\
\hline Observation & 72 & 72 & 72 & & \\
\hline
\end{tabular}

Note: Household income is measured as \# yuan/month; GDP is measured as \# 10,000 yuan/year; Industrial structure refers to the proportion of tertiary industrial output value (\%); Unemployment rate refers to the ratio of registered unemployed persons in urban areas to persons employed in urban units at year-end; Wage is measured as \# yuan/year; LTD refers to the loan to deposit ratio that is the ratio between loans and deposits of national banking system at year-end; Housing price is measured as \# yuan per square meter.

The second step is to use the regression results from Eq. (1) to decompose the mean difference in mean log incomes between the employed urban and rural migrants. The difference can be written as:

$$
\overline{\operatorname{Ln}\left(\text { Income }_{u}\right)}-\overline{\operatorname{Ln}\left(\text { Income }_{r}\right)}=\underbrace{\left(\overline{X_{u}}-\overline{X_{r}}\right)^{\prime} \beta^{*}}_{\text {Explained }}+\underbrace{\left(\overline{X_{u}}\right)^{\prime}\left(\beta_{u}-\beta^{*}\right)+\left(\overline{X_{r}}\right)^{\prime}\left(\beta^{*}-\beta_{r}\right)}_{\text {Unexplained }},
$$

where $\beta^{*}$ denotes a nondiscriminatory coefficients vector, which can be estimated from a pooled regression over both groups (Neumark, 1988). The first component is the part of 
the income difference that can be "explained" by the differences in individual characteristics between the two groups. The second component is the "unexplained" part, which is usually ascribed to discrimination in the literature (Démurger et al., 2009; Song, 2014). In order to ease the potential influence of differences in unobserved variables for the measurement of discrimination, we incorporate a variety of household and individual characteristics in the regression.

\subsection{Empirical approach and econometric models}

\subsubsection{The benchmark models}

The baseline regression with the outcome of entrepreneur is first estimated by the traditional ordinary least squares model, and further estimated by the mixed-effects model and twostage least squares method as robustness checks. The form of baseline regression model is set as follows:

$$
\text { Entrepreneur }_{i j}=\beta_{0}+\beta_{1} \text { Hukou discrimination }_{j}+\delta_{1} X_{i j}+\gamma_{p}+\varepsilon_{i j} \text {, }
$$

where Entrepreneur $r_{i j}$ is an indicator of entrepreneurship engagement for individual migrant $i$ in city $j$. Hukou discrimination ${ }_{j}$ is a continuous variable, which is measured by the citylevel average unexplained part estimated from Eq. (2) in city $j$. The vector of covariates $X_{i j}$ contains a set of individual-level and household-level variables as well as city-level factors summarized in Table 1. These variables are those typically suggested to be associated with individual's engagement on entrepreneurship in the literature (Chen \& $\mathrm{Hu}, 2019$; Evans \& Leighton, 1989; Li \& Wu, 2014; Schmalz et al., 2017). $\gamma_{p}$ represent province dummies that controlling the region-level fix effect. $\varepsilon_{i j}$ is an error term. The key interest in this paper is the value of $\beta_{1}$, which measures the relationship between city-level hukou discrimination and individual migrant's entrepreneurship.

Since only rural migrants are confronted with labor market discrimination based on rural hukou status, urban migrants' entrepreneurship decision should be insensitive to such discrimination. We will first test whether this is the case in the reality and if it is, we will focus on rural migrant samples from then on. We expect the coefficient of $\beta_{1}$ to be positive for rural migrants since, as the Hypothesis 1 has argued, rural migrants facing higher local hukou-based labor market discrimination may be more likely to engage in entrepreneurship.

We can use Eq. (3) to control the time-invariant unobservables due to the inclusion of regional dummies (random-intercept effects). However, estimates from Eq. (3) may be biased if the relationship between city-level hukou-based labor market discrimination and individual entrepreneurship varies across regions (random-slope effects). To ease this concern, we use the mixed-effects model to re-estimate Eq. (3) by using the following regression:

$$
\begin{aligned}
& \text { Entrepreneur }_{i j}=\beta_{0}+\beta_{1} \text { Hukou discrimination }_{j}+\delta_{1} X_{i j}+\gamma_{0, p}+ \\
& \gamma_{1, p} \times \text { Hukou discrimination }_{j}+\varepsilon_{i j},
\end{aligned}
$$

where $\gamma_{0, p}$ represent the random intercepts for each of $p$ provinces; $\gamma_{1, p}$ represent the random

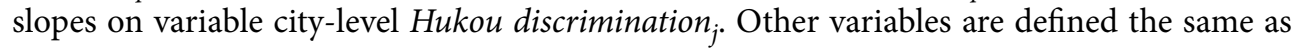
those in Eq. (3). 


\subsubsection{Extended models}

Individuals have positive factors that "pull" and negative factors that "push" them into entrepreneurial engagement (Block et al., 2015; van der Zwan et al., 2016). Pull motivations mainly arise from the need for inner satisfaction for achievement, independence and development, while push motivations mainly arise from the dissatisfaction with their current situation. Entrepreneurial activities driven mainly by push motivations are often labeled as necessitybased entrepreneurship, and those driven mainly by pull factors are called opportunity-based entrepreneurship (van der Zwan et al., 2016). Because of the labor market discrimination against rural hukou, rural migrants may be therefore forced to enter into an entrepreneurial career since there are no better choices for work. In other words, rural migrants may be more likely to engage into necessity-based entrepreneurship rather than opportunity-based entrepreneurship. To test this hypothesis, we use the multinomial logistic regression model with the following specification:

$$
\operatorname{Pr}\left(\text { Employment }_{i j}=1,2\right)=\beta_{0}+\beta_{1} \text { Hukou discrimination }_{j}+\delta_{1} X_{i j}+\gamma_{j}+\varepsilon_{i j} \text {, }
$$

where the dependent variable of Employment ${ }_{i j}$ takes three outcomes, which equals to 1 if individual $i$ is self-employed (necessity-based entrepreneurship), equals to 2 if individual $i$ is an employer (opportunity-based entrepreneurship) and equals to 0 otherwise. The definition of necessity-based and opportunity-based entrepreneurship is in line with previous studies $(\mathrm{Hu}, 2014)$. Other variables are the same as those defined previously.

\section{Statistical illustration}

\subsection{Estimates of hukou-based labor market discrimination}

Table 2 reports the Blinder-Oaxaca decomposition outcome of income according to Eq (2). As displayed in the Part A of Table 2, the mean of the log income is 8.347 for urban migrants and 8.088 for rural migrants, resulting in a log income gap of 0.259 . The difference is statistically significant at the 1 percent level. The log income gap can be divided into two parts. The first one is the explained part by group differences in individual characteristics. The coefficient of "Explained" suggests that differences in endowments between the two groups account for about 76.45 percent of the log income gap (i.e., $0.198 / 0.259=76.45 \%$ ). The second one is the unexplained part, which accounts for the remaining 23.55 percent of the log income gap (i.e., $0.061 / 0.259=23.55 \%$ ).

Part B of Table 2 reports the results transferred to the original scale from the logarithmic scale in the Part A. The means of income are 4,218 yuan/month for urban migrants and 3,255 yuan/month for rural migrants, which amounts to difference of 29.6 percent. Adjusting rural migrants' endowments levels to the levels of urban migrants would increase rural migrants' income by 21.9 percent. The remaining 6.3 percent cannot be explained by such group difference, which is arguably attributed to hukou-based discrimination in the labor market. 
Table 2. Blinder-Oaxaca decomposition of income

\begin{tabular}{|c|c|c|c|}
\hline \multirow{2}{*}{ Part A: Two-fold decomposition } & \multicolumn{2}{|c|}{ Mean } & \multirow{2}{*}{ Difference } \\
\hline & Urban migrants & Rural migrants & \\
\hline $\operatorname{Ln}($ Individual income) & $\begin{array}{c}8.347^{* * *} \\
(0.006)\end{array}$ & $\begin{array}{c}8.088^{\star * *} \\
(0.003)\end{array}$ & $\begin{array}{c}0.259^{* * *} \\
(0.007)\end{array}$ \\
\hline Explained & \multicolumn{3}{|c|}{$\begin{array}{c}0.198^{\star * *} \\
(0.004)\end{array}$} \\
\hline Unexplained & \multicolumn{3}{|c|}{$\begin{array}{c}0.061^{\star * *} \\
(0.007)\end{array}$} \\
\hline \multirow{2}{*}{ Part B: Exponentiated results } & \multicolumn{2}{|c|}{ Mean } & \multirow{2}{*}{ Difference } \\
\hline & Urban migrants & Rural migrants & \\
\hline Individual income & $\begin{array}{l}4,218^{\star * *} \\
(26.201)\end{array}$ & $\begin{array}{c}3,255^{\star * *} \\
(9.483)\end{array}$ & $\begin{array}{c}1.296^{* * *} \\
(0.009)\end{array}$ \\
\hline Explained & \multicolumn{3}{|c|}{$\begin{array}{c}1.219^{* * *} \\
(0.005)\end{array}$} \\
\hline Unexplained & \multicolumn{3}{|c|}{$\begin{array}{c}1.063^{* * *} \\
(0.007)\end{array}$} \\
\hline
\end{tabular}

Note: Robust standard errors in parentheses; ${ }^{* *} \mathrm{p}<0.01,{ }^{* *} \mathrm{p}<0.05,{ }^{*} \mathrm{p}<0.1$; Determinants of individual income includes education, gender, age, ethnicity, marital status, political status, occupation, industry, unit nature and location.

\subsection{City-level hukou discrimination and city-level migrants' entrepreneurship rate}

We first plot a scattered graph between the degree of average hukou-based labor market discrimination degree and the fraction of entrepreneurs of migrants in each city to sketch a general relationship between city-level hukou discrimination and city-level migrant entrepreneurship rate. We use the weight given in the CMDS as the frequency weight for the scatterplot, which visually causes the marker symbol area to be proportional to its weight. From Figure 1, we can see that city-level hukou discrimination in the labor market is positively associated with migrant's entrepreneurship rate in this city.

We further look at the relationship between city-level hukou discrimination degree and city-level migrant entrepreneurship rate in the subsamples of urban and rural migrants, respectively. The plotted graphs presented in Figure 2 suggest that there is a positive relationship between the two city-level variables in the group of rural migrants, while such correlation is much weak in the group of urban migrants.

\section{Regression analysis}

In this section, we first estimate the baseline regression to examine the relationship between city-level hukou discrimination degree and individual migrant's entrepreneurship likelihood. We find that the probability of migrant's entrepreneurial engagement is positively associated with the degree of city-level labor market discrimination against rural hukou holders. We also investigate whether the relationship between hukou discrimination and entrepreneurship varies across groups of rural and urban migrants. We find that with increasing degree of 


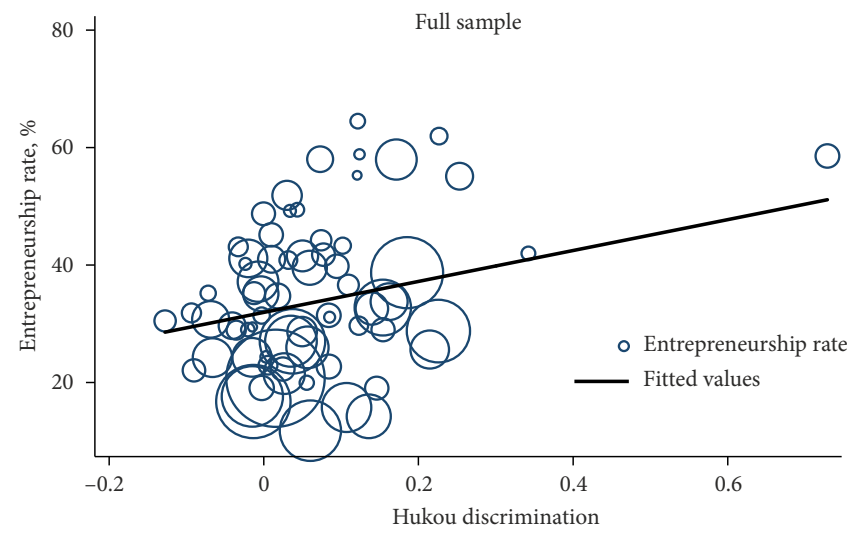

Note: City-level hukou discrimination is measured by the city-level average unexplained part of Blinder-Oaxaca decomposition of individual income between rural and urban migrants.

Figure 1. City-level hukou discrimination and migrant entrepreneurship (source: National Health Commission of China, 2016)
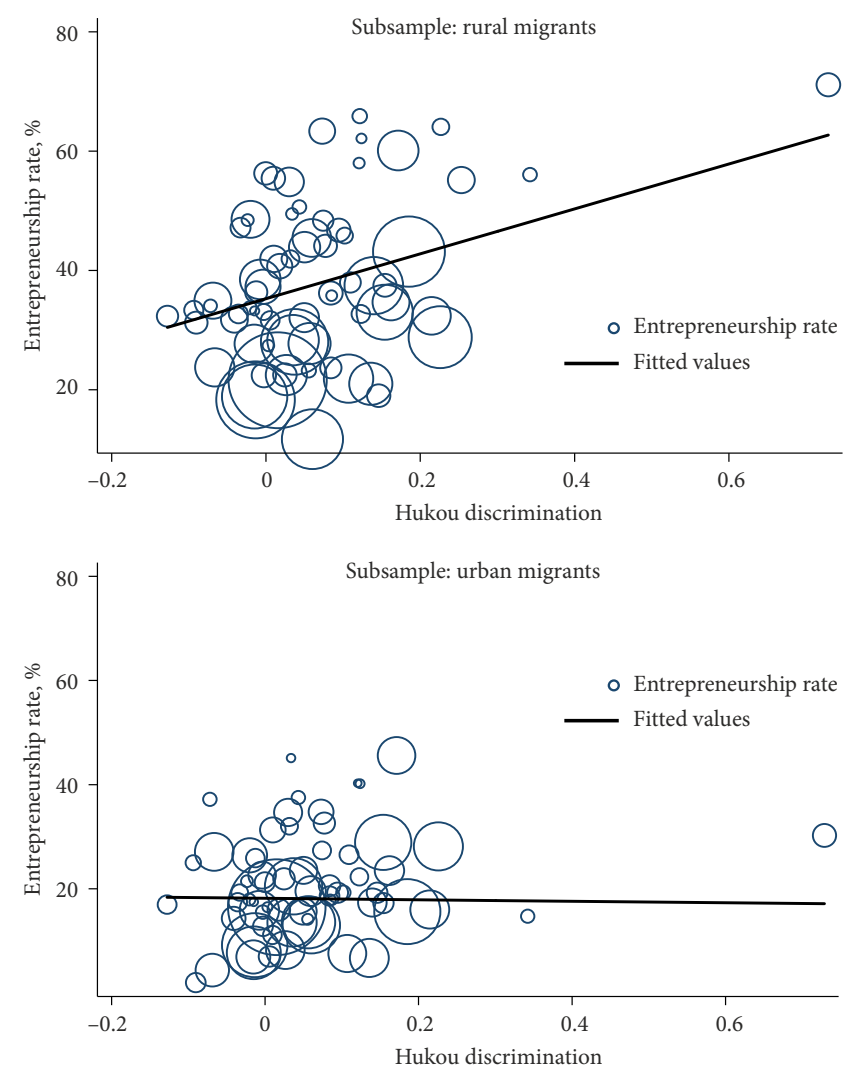

Note: City-level hukou discrimination is measured by the city-level average unexplained part of Blinder-Oaxaca decomposition of individual income between rural and urban migrants.

Figure 2. City-level hukou discrimination and migrant entrepreneurship (rural vs. urban migrants) (source: National Health Commission of China, 2016) 
city-level hukou discrimination, rural migrants are more likely to engage into entrepreneurship, while urban migrants do not change much in terms of the probability of entrepreneurship entry. We thus focus our analysis on rural migrants from then on. We further distinguish between so-called opportunity-based and necessity-based entrepreneurship and find that rural migrants more likely to be pushed into necessity-based entrepreneurship when there is a higher city-level hukou discrimination in the local labor market. Lastly, the relations between city-level hukou discrimination and entrepreneurship across several groups are examined.

\subsection{The benchmark results}

Column (1-3) in Table 3 displays the results of a series of different specifications by gradually increasing the number of controlled variables from the left to the right. Column (4) in Table 3 reports results of the test whether the relationship between hukou-based discrimination varies between rural and urban migrants.

Throughout columns (1)-(3) in Table 3, the regression results consistently suggest a positive relationship between city-level hukou-based discrimination and entrepreneurship among migrants, consistent with the graphic pattern observed in Figure 1. After controlling for individual and household characteristics (i.e., education, gender, age, ethnicity, marital status, political status, household income and homeownership status) and city-level factors (i.e., GDP, industrial structure, unemployment rate, wage, LTD and housing price), one standard deviation increase in a city's hukou discrimination is associated with roughly 2.9 percentage points' higher propensity of migrant's engaging in entrepreneurship. However, as discussed above, the labor market discrimination that related to rural hukou status is likely affecting those discriminated against-rural migrants, but should not affect those favored-urban migrants. Rural and urban migrants are therefore expected to respond differently to the degree of hukou discrimination in terms of the odds of entrepreneurship entry. To test this hypothesis, we add the interaction terms between hukou discrimination and rural hukou status into the baseline regression. Results reported in column (4) of Table 3 show that the estimated coefficient for the Hukou discrimination $\times$ Rural hukou is positive and statistically significant at the 1 percent level, while the coefficient for the Hukou discrimination is statistically insignificantly different from zero now. This finding suggests that hukou-based discrimination affects rural migrants' entrepreneurial propensity but not on urban migrants. We therefore restrict our attention to rural migrants in the analysis from now on.

Coefficients of other control variables in Table 3 are as expected by economic theory and are consistent with findings in most previous literature (Chen \& Hu, 2019; Hurst \& Lusardi, 2004; Li \& Wu, 2014; Schmalz et al., 2017). We skip the discussion of these variables since their effects are not the central focus of this paper.

\subsection{Robustness checks}

City-level degree of hukou discrimination in the labor market is found to be positively associated with indivdiual rural migrant's entrepreneurship in the data. We now deal with concerns on ommited variables and random effects across regions that could contaminate our previous estimations by controlling for regional unobeservables and using mixed-effects model and two-stage least squares (2SLS) model. 
Table 3. City-level hukou discrimination and migrant entrepreneurship (full sample)

\begin{tabular}{|c|c|c|c|c|}
\hline & $(1)$ & (2) & (3) & $(4)$ \\
\hline Hukou discrimination & $\begin{array}{c}0.024^{* * *} \\
(0.003)\end{array}$ & $\begin{array}{c}0.028^{* * *} \\
(0.003)\end{array}$ & $\begin{array}{c}0.029^{* * *} \\
(0.003)\end{array}$ & $\begin{array}{c}0.008 \\
(0.006)\end{array}$ \\
\hline Rural hukou & & $\begin{array}{c}0.080^{* * *} \\
(0.009)\end{array}$ & $\begin{array}{c}0.068^{\star * *} \\
(0.009)\end{array}$ & $\begin{array}{c}0.065^{\star * *} \\
(0.009)\end{array}$ \\
\hline \multirow{2}{*}{$\begin{array}{l}\text { Hukou discrimination } \times \\
\text { Rural hukou }\end{array}$} & & & & $0.025^{\star \star \star}$ \\
\hline & & & & $(0.007)$ \\
\hline \multicolumn{5}{|c|}{ Education (Ref.: Primary school or below) } \\
\hline 4-year college or above & & $\begin{array}{c}-0.359^{* * *} \\
(0.015)\end{array}$ & $\begin{array}{c}-0.342^{* * *} \\
(0.015)\end{array}$ & $\begin{array}{c}-0.340^{* * *} \\
(0.015)\end{array}$ \\
\hline 3-year college & & $\begin{array}{c}-0.224^{\star \star \star} \\
(0.015)\end{array}$ & $\begin{array}{c}-0.218^{\star \star \star} \\
(0.015)\end{array}$ & $\begin{array}{c}-0.217^{\star * \star} \\
(0.015)\end{array}$ \\
\hline Middle \& high school & & $\begin{array}{c}-0.036^{\star * \star} \\
(0.012)\end{array}$ & $\begin{array}{c}-0.032^{\star * *} \\
(0.012)\end{array}$ & $\begin{array}{c}-0.032^{\star \star \star} \\
(0.012)\end{array}$ \\
\hline Male & & $\begin{array}{c}0.035^{\star * *} \\
(0.006)\end{array}$ & $\begin{array}{c}0.034^{* * *} \\
(0.006)\end{array}$ & $\begin{array}{c}0.034^{* * *} \\
(0.006)\end{array}$ \\
\hline Age & & $\begin{array}{c}0.021^{* * *} \\
(0.003)\end{array}$ & $\begin{array}{c}0.021^{\star * *} \\
(0.003)\end{array}$ & $\begin{array}{c}0.021^{\star * *} \\
(0.003)\end{array}$ \\
\hline Age-squared & & $\begin{array}{c}-0.000^{\star * *} \\
(0.000)\end{array}$ & $\begin{array}{c}-0.000^{* * *} \\
(0.000)\end{array}$ & $\begin{array}{c}-0.000^{\star * *} \\
(0.000)\end{array}$ \\
\hline Han ethnicity & & $\begin{array}{c}0.062^{* * *} \\
(0.014)\end{array}$ & $\begin{array}{c}0.070^{* * *} \\
(0.014)\end{array}$ & $\begin{array}{c}0.070^{\star * *} \\
(0.014)\end{array}$ \\
\hline Married & & $\begin{array}{c}0.079^{\star * *} \\
(0.009)\end{array}$ & $\begin{array}{c}0.067^{\star * *} \\
(0.009)\end{array}$ & $\begin{array}{c}0.067^{\star * *} \\
(0.009)\end{array}$ \\
\hline Communist & & $\begin{array}{c}-0.033^{* *} \\
(0.013)\end{array}$ & $\begin{array}{c}-0.038^{* * *} \\
(0.013)\end{array}$ & $\begin{array}{c}-0.038^{\star * *} \\
(0.013)\end{array}$ \\
\hline Ln(Household income) & & $\begin{array}{c}0.162^{\star * *} \\
(0.006)\end{array}$ & $\begin{array}{c}0.210^{\star * *} \\
(0.007)\end{array}$ & $\begin{array}{c}0.211^{\star * *} \\
(0.007)\end{array}$ \\
\hline Homeowner & & $0.017^{\star \star}$ & $-0.017^{\star \star}$ & $-0.017^{\star *}$ \\
\hline & & $(0.007)$ & $(0.008)$ & $(0.008)$ \\
\hline \multicolumn{5}{|c|}{ City-level information } \\
\hline $\operatorname{Ln}(\mathrm{GDP})$ & & & $\begin{array}{c}-0.020^{\star * *} \\
(0.005)\end{array}$ & $\begin{array}{c}-0.020^{\star * \star} \\
(0.005)\end{array}$ \\
\hline Industrial structure & & & $\begin{array}{c}0.003^{\star * *} \\
(0.000)\end{array}$ & $\begin{array}{c}0.003^{\star * *} \\
(0.000)\end{array}$ \\
\hline Unemployment rate & & & $\begin{array}{c}1.221^{* * *} \\
(0.112)\end{array}$ & $\begin{array}{c}1.210^{* * *} \\
(0.112)\end{array}$ \\
\hline Ln(Wage) & & & $\begin{array}{c}-0.217^{\star * *} \\
(0.024)\end{array}$ & $\begin{array}{c}-0.213^{\star \star \star *} \\
(0.024)\end{array}$ \\
\hline LTD & & & $\begin{array}{c}0.119^{* * *} \\
(0.017)\end{array}$ & $\begin{array}{c}0.114^{* * *} \\
(0.017)\end{array}$ \\
\hline Ln(Housing price) & & & $\begin{array}{c}-0.037^{* * *} \\
(0.011)\end{array}$ & $\begin{array}{c}-0.039^{* * *} \\
(0.011)\end{array}$ \\
\hline Constant & $\begin{array}{c}0.347^{\star * *} \\
(0.003)\end{array}$ & $\begin{array}{c}-1.700^{\star * \star} \\
(0.070)\end{array}$ & $\begin{array}{c}0.763^{\star * *} \\
(0.207)\end{array}$ & $\begin{array}{c}0.763^{\star * *} \\
(0.207)\end{array}$ \\
\hline Observations & 61,621 & 61,621 & 61,621 & 61,621 \\
\hline R-squared & 0.002 & 0.139 & 0.164 & 0.164 \\
\hline
\end{tabular}

Note: Robust standard errors in parentheses; ${ }^{* *} \mathrm{p}<0.01,{ }^{* *} \mathrm{p}<0.05,{ }^{\star} \mathrm{p}<0.1$. 


\subsubsection{Addressing region-level fixed effects}

Previous estimations may be biased due to time-invariant regional unobservables omitted in the estimation. By including the province dummies into the regression, we can ease this concern and the estimation results are reported in Table 4. We can see that after controlling for unobserved heterogeneity of regional characteristics, one standard deviation increase in a city's hukou discrimination increases the entrepreneurship rate by 3.6 5.5 percentage points and the differences are statistically significant at the one percent level. These results reaffirm our previous findings.

Table 4. Hukou discrimination and entrepreneurship: regional heterogeneity (sample of rural migrants)

\begin{tabular}{|l|c|c|c|}
\hline & $(1)$ & $(2)$ & $(3)$ \\
\hline Hukou discrimination & $0.050^{\star * *}$ & $0.055^{\star * *}$ & $0.036^{* * *}$ \\
& $(0.005)$ & $(0.005)$ & $(0.005)$ \\
\hline Constant & $\begin{array}{c}0.467^{* * *} \\
(0.016)\end{array}$ & $\begin{array}{c}-2.004^{\star * *} \\
(0.080)\end{array}$ & $\begin{array}{c}-2.936^{* * *} \\
(0.429)\end{array}$ \\
\hline Individual \& household characteristics & No & Yes & Yes \\
\hline City-level information & No & No & Yes \\
\hline Province dummies & Yes & Yes & Yes \\
\hline Observations & 48,908 & 48,908 & 48,908 \\
\hline R-squared & 0.037 & 0.169 & 0.172 \\
\hline
\end{tabular}

Note: Robust standard errors in parentheses; ${ }^{* *} \mathrm{p}<0.01{ }^{* *} \mathrm{p}<0.05,{ }^{*} \mathrm{p}<0.1$; Control variables include individual \& household characteristics (i.e., education, gender, age, ethnicity, marital status, political status, household income and homeownership status) and city-level factors (i.e., GDP, industrial structure, unemployment rate, wage, LTD and housing price).

\subsubsection{Addressing region-level random effects}

Our above estimations are based on the fixed-effects hypothesis that independent variables only have constant effects on the dependent variables. However, if the effects of intercepts and slopes are random across subgroups of the sample rather than fixed, model structure as specified in previous equations is invalid. To deal with this potential issue, we apply mixedeffects model, the identification of which allows both fixed effects and random effects.

Results from Eq. (4) based on mixed-effects modeling are reported in Table 5. As shown in Part B of Table 5, the standard deviations of Hukou discrimination and Constant significantly are different from zero at the 1 percent level throughout columns (1) to (3) in this table, suggesting clear random-intercept and random-slop effects across regions. Table 5 also shows that there exists considerable province-level variation in the relationships between city-level hukou discrimination and migrant entrepreneurship. However, the results in Part A of Table 5 show that the coefficients of Hukou discrimination remain positive and do not change much in magnitudes compared with those reported in Table 4. We therefore conclude that the random regional heterogeneity of the estimated correlation does not posit serious threat to the main finding. 
Table 5. Hukou discrimination and entrepreneurship: mixed-effects model (sample of rural migrants)

\begin{tabular}{|l|c|c|c|}
\hline & $(1)$ & $(2)$ & $(3)$ \\
\hline \multicolumn{4}{|c|}{ Part A: Fixed-effects parameters } \\
\hline Hukou discrimination & $0.037^{* *}$ & $0.033^{* * *}$ & $0.041^{* * *}$ \\
& $(0.015)$ & $(0.012)$ & $(0.013)$ \\
\hline Constant & $0.442^{* * *}$ & $-2.141^{* * *}$ & $-1.468^{* * *}$ \\
& $(0.021)$ & $(0.053)$ & $(0.420)$ \\
\hline \multicolumn{4}{|c|}{ Part B: Random-effects parameters } \\
\hline Hukou discrimination & $0.063^{* * *}$ & $0.051^{* * *}$ & $0.057^{* * *}$ \\
& $(0.012)$ & $(0.010)$ & $(0.011)$ \\
\hline Constant & $0.111^{* * *}$ & $0.111^{* * *}$ & $0.105^{* * *}$ \\
& $(0.016)$ & $(0.016)$ & $(0.015)$ \\
\hline Individual \& household characteristics & No & Yes & Yes \\
\hline City-level information & No & No & Yes \\
\hline Observations & 48,908 & 48,908 & 48,908 \\
\hline LR test vs. linear model: chi2(2) & $2280.87^{* * *}$ & $2976.97^{* * *}$ & $1373.16^{* * *}$ \\
\hline
\end{tabular}

Note: Robust standard errors in parentheses; ${ }^{* \star} \mathrm{p}<0.01{ }^{\star *} \mathrm{p}<0.05,{ }^{\star} \mathrm{p}<0.1$; Control variables include individual \& household characteristics (i.e., education, gender, age, ethnicity, marital status, political status, household income and homeownership status) and city-level factors (i.e., GDP, industrial structure, unemployment rate, wage, LTD and housing price).

\subsubsection{Addressing potential effects of endogeneity and self-sorting}

Another concern is the potential endogeneity bias in the analysis as some omitted city-level variables could simultaneously impact both the degree of hukou discrimination and the individual choice of entrepreneurship. For example, as documented in the literature, there is a close nexus between entrepreneurship and institutions (Acs et al., 2008; Aidis et al., 2008; Liu et al., 2019); besides, institutional factors are important determinants of migration flows (Shen, 2013; Wu, 2006). To address this concern, we use the city's proportion of migrants in the year of 2003 to instrument for the current degree of hukou discrimination in this city $^{2}$. The year 2003 is the earliest year that we can obtain the city-level migrant population statistics. This instrument variable should be valid. On the one hand, the proportion of migrants in 2003 is highly correlated with the current concentration of migrant people, which is negatively associated with the degree of city-level hukou discrimination. On the other hand, the historical proportion of migrants is not directly correlated with the current entrepreneurial engagement of migrants. The results of underidentification test and weak identification test to this instrument variable are reported in Table 6, showing the validness of this instrument variable.

Table 6 presents the results of the two-stage least squares (2SLS) model. In the first stage results reported in Column (2), increase in the concentration of migrants decreases the citylevel hukou discrimination degree. In the second stage results reported in Column (1), the predicted city-level hukou discrimination has a positive and significant relationship with en-

\footnotetext{
2 The data of proportion of migrants in each city is obtained from the 2004 China City Statistical Yearbook.
} 
trepreneurship. A one standard deviation increase in a city's hukou discrimination increases the likelihood of entering entrepreneurship of migrants by 4.9 percentage points. This result reinforces our previous finding.

We also place attention to the issue of potential self-selection bias, which arises if the subsample of migrants in each city is not randomly sampled from the entire population of migrants. For example, migrants who have stronger entrepreneurial propensity may be more tolerant of hukou discrimination that most occurs in big cities with more entrepreneurial opportunities. If this is the case, our previous estimators may suffer from self-selection bias. To alleviate this potential bias, we implement the Heckman model by defining an indicator variable of high degree of hukou-based discrimination, which equals to one if the hukoubased discrimination is higher than the mean value and equals to zero otherwise. Results suggest that the Heckman estimator of the hukou discrimination is quite similar to the corresponding baseline regression result ( $2.8 \%$ vs. $2.9 \%)$, and the coefficient is still statistically significant at the $1 \%$ level.

Table 6. Hukou discrimination and entrepreneurship: 2SLS (sample of rural migrants)

\begin{tabular}{|c|c|c|}
\hline & (1) & (2) \\
\hline & 2nd stage regression & 1st stage regression \\
\hline & Y: Entrepreneur & Y: Hukou discrimination \\
\hline Hukou discrimination & $\begin{array}{c}0.049^{* * *} \\
(0.012)\end{array}$ & \\
\hline Proportion of migrants & & $\begin{array}{c}-2.090^{* * *} \\
(0.041)\end{array}$ \\
\hline Constant & $\begin{array}{c}0.802^{\star * *} \\
(0.233)\end{array}$ & $\begin{array}{c}11.827^{* * *} \\
(0.468)\end{array}$ \\
\hline Individual \& household characteristics & Yes & Yes \\
\hline City-level information & Yes & Yes \\
\hline \multicolumn{3}{|c|}{ Underidentification test } \\
\hline Kleibergen-Paap rk LM statistic & \multicolumn{2}{|c|}{$2196.276^{* * *}$} \\
\hline \multicolumn{3}{|c|}{ Weak identification test } \\
\hline Kleibergen-Paap rk Wald F statistic & \multicolumn{2}{|c|}{2572.573} \\
\hline $10 \%$ maximal IV size & \multicolumn{2}{|c|}{16.38} \\
\hline Observations & 48,908 & 48,908 \\
\hline R-squared & 0.152 & 0.204 \\
\hline
\end{tabular}

Note: Robust standard errors in parentheses; ${ }^{* *} \mathrm{p}<0.01$, ${ }^{* *} \mathrm{p}<0.05,{ }^{*} \mathrm{p}<0.1$; Control variables include individual \& household characteristics (i.e., education, gender, age, ethnicity, marital status, political status, household income and homeownership status) and city-level factors (GDP, industrial structure, unemployment rate, wage, LTD and housing price); We instrument hukou discrimination in the labor market with the proportion of migrants in a city.

\subsection{Hukou-based discrimination and entrepreneurial choices}

In this section, we are concerning the rural migrants who are discriminated against in the labor market and choose to enter into entrepreneurship, are their entrepreneurial intentions motivated more by "pull" or more by "push" factors? To answer this question, we estimate Eq. (5) and the results are reported in Table 7. 
Table 7. Hukou discrimination and entrepreneurship: necessity vs. opportunity-based entrepreneurs (sample of rural migrants)

\begin{tabular}{|l|c|c|}
\hline \multirow{2}{*}{} & $(1)$ & $(2)$ \\
\cline { 2 - 3 } & $\begin{array}{c}\text { Opportunity-based } \\
\text { entrepreneur }\end{array}$ & $\begin{array}{c}\text { Necessity-based } \\
\text { entrepreneur }\end{array}$ \\
\cline { 2 - 3 } & \multicolumn{2}{|c|}{ Coef. } \\
\hline Hukou discrimination & $\begin{array}{c}0.099^{* * *} \\
(0.028) \\
{[0.002]}\end{array}$ & $\begin{array}{c}0.170^{* * *} \\
(0.018) \\
{[0.028]}\end{array}$ \\
\hline Constant & $\begin{array}{c}3.212^{* * *} \\
\left(10.018^{* * *}\right. \\
(2.085)\end{array}$ \\
\hline Individual \& household characteristics & \multicolumn{2}{|c|}{ Yes } \\
\hline City-level information & \multicolumn{2}{|c|}{ Yes } \\
\hline Province dummies & \multicolumn{2}{|c|}{48,908} \\
\hline Observations & \multicolumn{2}{|c|}{0.1212} \\
\hline Pseudo R-squared & \multicolumn{2}{|c|}{} \\
\hline
\end{tabular}

Note: Sample in this table is restricted to rural migrants; Results are estimated by the multinomial logistic regression (employees are categorized into the base group); Robust standard errors in parentheses; Marginal effects in square brackets; ${ }^{* * *} \mathrm{p}<0.01,{ }^{* *} \mathrm{p}<0.05,{ }^{\star} \mathrm{p}<0.1$; Control variables include individual \& household characteristics (i.e., education, gender, age, ethnicity, marital status, political status, household income and homeownership status) and city-level factors (i.e., GDP, industrial structure, unemployment rate, wage, LTD and housing price).

The key estimator is called marginal effect, which has a similar interpretation to the coefficients in the ordinary least squares model. The estimated marginal effects, as reported in the square brackets in Table 7, suggest that for one standard deviation increase in the degree of hukou discrimination, the probability of being an opportunity-based entrepreneur increases by $2.8 \%$, while the probability of being a necessity-based entrepreneur only increases by $0.2 \%$. Necessity and opportunity-based entrepreneurs are often distinguished by "push" and "pull" motivations (Block et al., 2015; van der Zwan et al., 2016). Our empirical finding suggests that migrant entrepreneurs who have a rural hukou are more likely to engage into necessitybased entrepreneurship driven by push factors, in line with the second hypothesis. For this reason, we will focus on the necessity-based entrepreneurship in the next section discussing the heterogeneity effect of hukou discrimination among groups with different demographic and socio-economic characteristics.

\subsection{Further examinations: the cross effects of education, age, marital status and homeownership}

We now include interaction terms between hukou discrimination and several household characteristics into the baseline regression model. The results are displayed in Table 8 . We begin the model specification by including interaction terms between hukou discrimination and four education dummies, which are 4-year college or above, 3-year college, Middle \& high school and Primary school or below. As shown in Column (1) of Table 8, the coefficient of the interaction between hukou discrimination and Middle \& high school is statistically significant 
at the one percent level, while the other three interactions are insignificant. The differentials observed are as expected given that high-educated people are less likely to be involved in entrepreneurship that attaches high risk (Chen \& Hu, 2019; Li \& Wu, 2014); besides, entrepreneurial ability that consists of the knowledge structures is critical in the recognition, identification and creation of entrepreneurial opportunities, and thus a certain level of education is necessary for entrepreneurs (Miller, 2007; Mitchell et al., 2000).

We continue by testing whether the nexus of hukou discrimination and entrepreneurship varies across age groups. The results, as displayed in Column (2) of Table 8, suggest that the association between hukou discrimination and entrepreneurship weakens with the increase of age. Holding other things equal, a one standard deviation increase in the degree of hukou discrimination will increase the probability of entrepreneurship by 4.0 percentage points for migrants aged below 30, while the influence decreases to 3.7 percentage points for age group 31-40 years, to 2.4 percentage points for the $41-40$ group and further to 0.2 percentage points for the group aged above 51. This influence becomes even insignificant for the group aged above 51. Prudence is positively associated with the age-related increase of responsibility. The differences in the hukou discrimination-entrepreneurship relationship across age groups are likely due to the fact that people more risk averse over time (Mandal \& Roe, 2014); besides, the opportunity cost of entrepreneurship is especially large for middleage adults who are more likely to find good employment positions by virtue of their high degree of human capital accumulated.

In the Column (3) of Table 8, we distinguish the heterogeneity effect of hukou discrimination between single and married migrants. The results indicate that married migrants are more likely to engage into entrepreneurship with the increase of hukou discrimination than their single counterparts. Possible reason for this difference in impact (coefficient of 0.035 vs. 0.019 ) is that the family members of self-employer often participate into the entrepreneurial activity to increase the pooling of labor power (Mandal \& Roe, 2014). Employment of unpaid family labor decreases the entrepreneurial cost and makes married migrants more sensitive to hukou discrimination in the labor market.

Since the preference for risk between homeowners and renters differs, we expect different responses to hukou discrimination in terms of the probability of entrepreneurship entry for these two groups. We report results by adding the interaction terms between hukou discrimination and housing tenure dummies (homeowner and renter) into the baseline regression in the last Column of Table 8. As expected, homeowners and renters show different entrepreneurial engagement when faced with hukou-based discrimination. For a one standard deviation increase in the degree of hukou discrimination, the increase in the likelihood of entrepreneurial engagement for homeowners is 2.3 percentage points vs. 3.4 percentage points for renters, after controlling for household observables and unobserved regional characteristics. This is consistent with the ample findings on the higher risk preference for renters compared with homeowners (Lundborg \& Skedinger, 1999; Modestino \& Dennett, 2013) ${ }^{3}$.

\footnotetext{
${ }^{3}$ Chen and $\mathrm{Hu}(2019)$ summarize four mechanisms underlying why homeownership would impact entrepreneurship; these are collateral effect (external financing through collateralized housing assets), wealth effect (the huge value of housing assets allows the pursue of the non-pecuniary benefits associated with owning a business), lock-in effect (homeowners under loan repayment pressure will be more likely to be locked in their current jobs), and crowding-out effect (homeownership, particularly of homes leveraged by mortgages, significantly limits a household's engagement in risky activities).
} 
Table 8. Hukou discrimination and entrepreneurship: heterogeneity across groups (sample of rural migrants)

\begin{tabular}{|c|c|c|c|c|}
\hline & (1) & (2) & (3) & (4) \\
\hline \multicolumn{5}{|c|}{ Hukou discrimination } \\
\hline 4-year college or above & $\begin{array}{c}-0.002 \\
(0.014)\end{array}$ & & & \\
\hline 3-year college & $\begin{array}{c}0.012 \\
(0.010)\end{array}$ & & & \\
\hline Middle \& high school & $\begin{array}{c}0.041^{* * *} \\
(0.004)\end{array}$ & & & \\
\hline Primary school or below & $\begin{array}{c}0.005 \\
(0.010) \\
\end{array}$ & & & \\
\hline \multicolumn{5}{|c|}{ Hukou discrimination } \\
\hline Aged above 51 & & $\begin{array}{l}-0.002 \\
(0.015)\end{array}$ & & \\
\hline Aged between 41 and 50 & & $\begin{array}{c}0.024^{* * *} \\
(0.007)\end{array}$ & & \\
\hline Aged between 31 and 40 & & $\begin{array}{c}0.037^{* * *} \\
(0.006)\end{array}$ & & \\
\hline Aged below 30 & & $\begin{array}{c}0.040^{* * *} \\
(0.005)\end{array}$ & & \\
\hline \multicolumn{5}{|c|}{ Hukou discrimination } \\
\hline Single & & & $\begin{array}{c}0.019^{* * *} \\
(0.006)\end{array}$ & \\
\hline Married & & & $\begin{array}{c}0.035^{* * *} \\
(0.004)\end{array}$ & \\
\hline \multicolumn{5}{|c|}{ Hukou discrimination } \\
\hline Homeowner & & & & $\begin{array}{c}0.023^{* * *} \\
(0.008)\end{array}$ \\
\hline Renter & & & & $\begin{array}{c}0.034^{\star * *} \\
(0.004) \\
\end{array}$ \\
\hline Constant & $\begin{array}{c}0.788^{\star * *} \\
(0.232)\end{array}$ & $\begin{array}{c}0.797^{* * *} \\
(0.233)\end{array}$ & $\begin{array}{c}0.804^{* * *} \\
(0.232)\end{array}$ & $\begin{array}{c}0.808^{\star * *} \\
(0.232)\end{array}$ \\
\hline Individual \& household characteristics & Yes & Yes & Yes & Yes \\
\hline City-level information & Yes & Yes & Yes & Yes \\
\hline Province dummies & Yes & Yes & Yes & Yes \\
\hline Observations & 48,908 & 48,908 & 48,908 & 48,908 \\
\hline R-squared & 0.154 & 0.154 & 0.153 & 0.153 \\
\hline
\end{tabular}

Note: Sample in this table is restricted to rural migrants; Robust standard errors in parentheses; ${ }^{* * *}$ $\mathrm{p}<0.01,{ }^{* *} \mathrm{p}<0.05,{ }^{*} \mathrm{p}<0.1$; Control variables include individual \& household characteristics (i.e., education, gender, age, ethnicity, marital status, political status, household income and homeownership status) and city-level factors (i.e., GDP, industrial structure, unemployment rate, wage, LTD and housing price). 


\section{Conclusions}

The literature has suggested that, entrepreneurship is a possible way out of discrimination in paid-employment for individuals with a disadvantageous social identity generated by this institutional arrangement. However, few existing studies of entrepreneurship have carefully examined the linkage between hukou-based discrimination and entrepreneurship. This paper estimates the degree of city-level labor market discrimination against rural hukou among migrants in urban China and investigates its relationship to rural migrants' entrepreneurship tendency.

Using data from the China Migrants Dynamic Survey (CMDS), we find that hukou discrimination can explain a $6.3 \%$ decrease in personal income for rural migrants relative to comparable urban migrants. We also find that migrants are more likely to engage into entrepreneurship in cities with high degree of hukou-based discrimination. One standard deviation increase in a city's hukou discrimination is associated with roughly 2.9 percentage points' higher propensity of engaging in entrepreneurship, holding other things constant. This finding remains robust across a wide variety of model specifications, including regional fixed-effects model, mixed-effects model and two-stage least squares model. The heterogeneity relationships between hukou discrimination and entrepreneurship are further examined and several interesting findings are revealed. First, hukou-based discrimination mainly induces rural migrants but not urban migrants to start an entrepreneurial activity. Second, hukou discrimination is associated with much higher propensity for engagement in necessity-based entrepreneur instead of opportunity-based entrepreneur. Third, the association between hukou discrimination and migrant entrepreneurship is more prominent for people with a certain level of education, young people, married people and renters.

The present findings have several practical implications. Our results show a general positive relationship between hukou discrimination and entrepreneurship, while it also shows that discrimination in the labor market "pushes" rural migrant into necessity-based entrepreneurship. In other words, entrepreneurship is in most cases not the preferred choice for rural migrants who start their own businesses due to necessity motives. These findings suggest that entrepreneurship may not an improvement in welfare for rural entrepreneurs. Governments should attach great importance to the issue of fairness in the labor market and the wellbeing of rural entrepreneurs.

Surely, the degree of labor market discrimination against rural hukou and its relation to migrant entrepreneurship is expected to change correspondingly with local labor market conditions. Future analysis is warranted to discuss how the major findings in this paper can be generalized to other institutional contexts.

\section{Acknowledgements}

The authors are grateful for financial support from the National Natural Science Foundation of China (No. 71974125, No. 71661137004 and No. 71774144), the Natural Science Foundation of Guangdong Province (No. 2020A1515010359), and the Major Research Project of Philosophy and Social Sciences of the Ministry of Education (18JZD033). 


\section{References}

Acs, Z., Desai, S., \& Hessels, J. (2008). Entrepreneurship, economic development and institutions. Small Business Economics, 31(3), 219-234. https://doi.org/10.1007/s11187-008-9135-9

Afridi, F., Li, S. X., \& Ren, Y. (2015). Social identity and inequality: The impact of China's hukou system. Journal of Public Economics, 123, 17-29. https://doi.org/10.1016/j.jpubeco.2014.12.011

Aidis, R., Estrin, S., \& Mickiewicz, T. (2008). Institutions and entrepreneurship development in Russia: A comparative perspective. Journal of Business Venturing, 23(6), 656-672.

https://doi.org/10.1016/j.jbusvent.2008.01.005

Bates, T., Jackson, W. E., \& Johnson, J. H. (2007). Advancing research on minority entrepreneurship. The ANNALS of the American Academy of Political and Social Science, 613(1), 10-17. https://doi.org/10.1177/0002716207303405

Birley, S., \& Westhead, P. (1994). A Taxonomy of business start-up reasons and their impact on firm growth and size. Journal of Business Venturing, 9(1), 7-31. https://doi.org/10.1016/0883-9026(94)90024-8

Block, J. H., Kohn, K., Miller, D., \& Ullrich, K. (2015). Necessity entrepreneurship and competitive strategy. Small Business Economics, 44(1), 37-54. https://doi.org/10.1007/s11187-014-9589-x

Carter, N. M., Gartner, W. B., Shaver, K. G., \& Gatewood, E. J. (2003). The career reasons of nascent entrepreneurs. Journal of Business Venturing, 18(1), 13-39.

https://doi.org/10.1016/S0883-9026(02)00078-2

Chan, K. W. (2013). China: Internal migration. In I. Ness \& P. Bellwood (Eds.), The Encyclopedia of global human migration. Blackwell Publishing Ltd. https://doi.org/10.1002/9781444351071.wbeghm124

Chan, K. W., \& Buckingham, W. (2008). Is China abolishing the hukou system? The China Quarterly, 195(6), 582-606. https://doi.org/10.1017/S0305741008000787

Chan, K. W., \& Zhang, L. (1999). The hukou system and rural-urban migration in China: Processes and changes. The China Quarterly, 160(1), 818-855. https://doi.org/10.1017/S0305741000001351

Chen, J., \& Hu, M. (2019). What types of homeowners are more likely to be entrepreneurs? The evidence from China. Small Business Economics, 52(3), 633-649. https://doi.org/10.1007/s11187-017-9976-1

Chen, J., \& Wang, W. (2019). Economic incentives and settlement intentions of rural migrants: Evidence from China. Journal of Urban Affairs, 41(3), 372-389. https://doi.org/10.1080/07352166.2018.1439339

Clark, K., \& Drinkwater, S. (2000). Pushed out or pulled in? Self-employment among ethnic minorities in England and Wales. Labour Economics, 7(5), 603-628. https://doi.org/10.1016/S0927-5371(00)00015-4

Coate, S., \& Tennyson, S. (1992). Labor market discrimination, imperfect information and self employment. Oxford Economic Papers, 44(2), 272-288. https://doi.org/10.1093/oxfordjournals.oep.a042046

Constant, A., \& Zimmermann, K. F. (2006). The making of entrepreneurs in Germany: Are native men and immigrants alike? Small Business Economics, 26(3), 279-300. https://doi.org/10.1007/s11187-005-3004-6

Démurger, S., Gurgand, M., Li, S., \& Yue, X. (2009). Migrants as second-class workers in urban China? A decomposition analysis. Journal of Comparative Economics, 37(4), 610-628.

https://doi.org/10.1016/j.jce.2009.04.008

Evans, D., \& Leighton, L. (1989). Some empirical aspects of entrepreneurship. American Economic Review, 79(3), 519-535. https://www.jstor.org/stable/1806861

Fossen, F. (2012). Gender differences in entrepreneurial choice and risk aversion - A decomposition based on a microeconometric model. Applied Economics, 44(14), 1795-1812.

https://doi.org/10.1080/00036846.2011.554377 
Gagnon, J., Xenogiani, T., \& Xing, C. (2011). Are all migrants really worse off in urban labour markets? New empirical evidence from China (IZA Discussion Paper No. 6268). https://ssrn.com/abstract $=1981224$

Glaeser, E., Rosenthal, S., \& Strange, W. (2010). Urban economics and entrepreneurship. Journal of Urban Economics, 67(1), 1-14. https://doi.org/10.1016/j.jue.2009.10.005

Guo, C., \& Miller, J. K. (2010). Guanxi dynamics and entrepreneurial firm creation and development in China. Management and Organization Review, 6(2), 267-291. https://doi.org/10.1111/j.1740-8784.2010.00180.x

Hisrich, R. D., \& Brush, C. (1986). Characteristics of the minority entrepreneur. Journal of Small Business Management, 24, 1-8.

Hu, F. (2014). Risk attitudes and self-employment in China. China \& World Economy, 22(3), 101-120. https://doi.org/10.1111/j.1749-124X.2014.12070.x

Hurst, E., \& Lusardi, A. (2004). Liquidity constraints, household wealth, and entrepreneurship. Journal of Political Economy, 112(2), 319-347. https://doi.org/10.1086/381478

Kahn, S., La Mattina, G., \& J. MacGarvie, M. (2017). “Misfits," “Stars,” and immigrant entrepreneurship. Small Business Economics, 49(3), 533-557. https://doi.org/10.1007/s11187-017-9848-8

Köllinger, P., \& Minniti, M. (2006). Not for lack of trying: American entrepreneurship in black and white. Small Business Economics, 27(1), 59-79. https://doi.org/10.1007/s11187-006-0019-6

Lee, L. (2012). Decomposing wage differentials between migrant workers and urban workers in urban China's labor markets. China Economic Review, 23(2), 461-470. https://doi.org/10.1016/j.chieco.2012.03.004

Li, L., \& Wu, X. (2014). Housing price and entrepreneurship in China. Journal of Comparative Economics, 42(2), 436-449. https://doi.org/10.1016/j.jce.2013.09.001

Liu, C. Y. (2012). Intrametropolitan opportunity structure and the self-employment of Asian and Latino immigrants. Economic Development Quarterly, 26(2), 178-192. https://doi.org/10.1177/0891242412443126

Liu, J., Hu, M., Zhang, H., \& Carrick, J. (2019). Corruption and entrepreneurship in emerging markets. Emerging Markets Finance and Trade, 55(5), 1051-1068. https://doi.org/10.1080/1540496X.2018.1531242

Liu, Z. (2005). Institution and Inequality: The Hukou System in China. Journal of Comparative Economics, 33(1), 133-157. https://doi.org/10.1016/j.jce.2004.11.001

Lu, M., \& Wan, G. (2014). Urbanization and urban systems in the People'S Republic of China: Research findings and policy recommendations. Journal of Economic Surveys, 28(4), 671-685. https://doi.org/10.1111/joes.12078

Lundborg, P., \& Skedinger, P. (1999). Transaction taxes in a search model of the housing market. Journal of Urban Economics, 45(2), 385-399. https://doi.org/10.1006/juec.1998.2103

$\mathrm{Ma}, \mathrm{X}$. (2018). Labor market segmentation by industry sectors and wage gaps between migrants and local urban residents in urban China. China Economic Review, 47, 96-115. https://doi.org/10.1016/j.chieco.2017.11.007

Mandal, B., \& Roe, B. E. (2014). Risk tolerance among national longitudinal survey of youth participants: The effects of age and cognitive skills. Economica, 81(323), 522-543. https://doi.org/10.1111/ecca.12088

Meng, X. (2012). Labor market outcomes and reforms in China. The Journal of Economic Perspectives, 26(4), 75-102. https://doi.org/10.1257/jep.26.4.75

Meng, X., \& Zhang, J. (2001). The two-tier labor market in urban China: Occupational segregation and wage differentials between urban residents and rural migrants in Shanghai. Journal of Comparative Economics, 29(3), 485-504. https://doi.org/10.1006/jcec.2001.1730 
Miller, K. D. (2007). Risk and rationality in entrepreneurial processes. Strategic Entrepreneurship Journal, 1(1-2), 57-74. https://doi.org/10.1002/sej.2

Mitchell, R. K., Smith, B., Seawright, K. W., \& Morse, E. A. (2000). Cross-cultural cognitions and the venture creation decision. Academy of Management Journal, 43(5), 974-993.

https://doi.org/10.5465/1556422

Modestino, A. S., \& Dennett, J. (2013). Are American homeowners locked into their houses? The impact of housing market conditions on state-to-state migration. Regional Science and Urban Economics, 43(2), 322-337. https://doi.org/10.1016/j.regsciurbeco.2012.08.002

Müller, T. (2003). Migration, unemployment and discrimination. European Economic Review, 47(3), 409-427. https://doi.org/10.1016/S0014-2921(01)00177-5

Muravyev, A., Talavera, O., \& Schäfer, D. (2009). Entrepreneurs' gender and financial constraints: Evidence from international data. Journal of Comparative Economics, 37(2), 270-286. https://doi.org/10.1016/j.jce.2008.12.001

National Bureau of Statistics of China. (2017). China City Statistical Yearbook. http://www.stats.gov.cn/enGliSH/

National Health Commission of China. (2016). China migrants dynamic survey. https://www.chinaldrk.org.cn/wjw/\#/home

Naudé, W. (2011). Entrepreneurship and economic development: An introduction. In W. Naudé (Ed.), Studies in development economics and policy. Entrepreneurship and economic development (pp. 3-17). Palgrave Macmillan UK. https://doi.org/10.1057/9780230295155_1

Neumark, D. (1988). Employers' discriminatory behavior and the estimation of wage discrimination. The Journal of Human Resources, 23(3), 279-295. https://doi.org/10.2307/145830

Oxenfeldt, A. (1943). New firms and free enterprise. American Council on Public Affairs. https://www. worldcat.org/title/new-firms-and-free-enterprise-pre-war-and-post-war-aspects/oclc/2084075

Parker, S. C. (2005). Explaining regional variations in entrepreneurship as multiple occupational equilibria. Journal of Regional Science, 45(4), 829-850. h https://doi.org/10.1111/j.0022-4146.2005.00394.x

Raijman, R., \& Tienda, M. (2000). Immigrants' pathways to business ownership: A comparative ethnic perspective. International Migration Review, 34(3), 682-706. https://doi.org/10.1177/019791830003400302

Rocha, V., Carneiro, A., \& Varum, C. A. (2015). Entry and exit dynamics of nascent business owners. Small Business Economics, 45(1), 63-84. https://doi.org/10.1007/s11187-015-9641-5

Rosti, L., \& Chelli, F. (2005). Gender discrimination, entrepreneurial talent and self-employment. Small Business Economics, 24(2), 131-142. https://doi.org/10.1007/s11187-003-3804-5

Schmalz, M., Sraer, D., \& Thesmar, D. (2017). Housing collateral and entrepreneurship. The Journal of Finance, 72(1), 99-132. https://doi.org/10.1111/jofi.12468

Shane, S., Kolvereid, L., \& Westhead, P. (1991). An exploratory examination of the reasons leading to new firm formation across country and gender. Journal of Business Venturing, 6(6), 431-446. https://doi.org/10.1016/0883-9026(91)90029-D

Shen, J. (2013). Increasing internal migration in China from 1985 to 2005: Institutional versus economic drivers. Habitat International, 39, 1-7. https://doi.org/10.1016/j.habitatint.2012.10.004

Simoes, N., Crespo, N., \& Moreira, S. B. (2016). Individual determinants of self-employment entry: What do we really know? Journal of Economic Surveys, 30(4), 783-806.

https://doi.org/10.1111/joes.12111

Song, Y. (2014). What Should economists know about the current Chinese Hukou System? China Economic Review, 29, 200-212. https://doi.org/10.1016/j.chieco.2014.04.012

Stanworth, J., Stanworth, C., Granger, B., \& Blyth, S. (1989). Who becomes an entrepreneur? International Small Business Journal: Researching Entrepreneurship, 8(1), 11-22.

https://doi.org/10.1177/026624268900800101 
Stephens, H. M., Partridge, M. D., \& Faggian, A. (2013). Innovation, entrepreneurship and economic growth in lagging regions. Journal of Regional Science, 53(5), 778-812. https://doi.org/10.1111/jors.12019

Thurik, A. R., Carree, M. A., van Stel, A., \& Audretsch, D. B. (2008). Does self-employment reduce unemployment? Journal of Business Venturing, 23(6), 673-686. https://doi.org/10.1016/j.jbusvent.2008.01.007

van der Zwan, P., Thurik, R., Verheul, I., \& Hessels, J. (2016). Factors influencing the entrepreneurial engagement of opportunity and necessity entrepreneurs. Eurasian Business Review, 6(3), 273-297. https://doi.org/10.1007/s40821-016-0067-z

Wei, X., Jiao, Y., \& Growe, G. (2019). Language skills and migrant entrepreneurship: Evidence from China. Small Business Economics, 53(4), 981-999. https://doi.org/10.1007/s11187-018-0105-6

Westlund, H., \& Bolton, R. (2003). Local social capital and entrepreneurship. Small Business Economics, 21(2), 77-113. https://doi.org/10.1023/A:1025024009072

Williams, D. R. (2012). Gender discrimination and self-employment dynamics in Europe. The Journal of Socio-Economics, 41(2), 153-158. https://doi.org/10.1016/j.socec.2011.08.029

Wu, W. (2006). Migrant intra-urban residential mobility in urban China. Housing Studies, 21(5), $745-$ 765. https://doi.org/10.1080/02673030600807506

Zhang, L., Sharpe, R. V., Li, S., \& Darity, W. A. J. (2016). Wage differentials between urban and ruralurban migrant workers in China. China Economic Review, 41(1), 222-233. https://doi.org/10.1016/j.chieco.2016.10.004

Zou, J., Chen, Y., \& Chen, J. (2019). The complex relationship between neighbourhood types and migrants' socio-economic integration: the case of urban China. Journal of Housing and the Built Environment, 35, 65-92. https://doi.org/10.1007/s10901-019-09670-2 